\title{
The Meeting of Multiple Words and Worlds
}

\author{
GALICIA S.T. BLACKMAN \\ University of Calgary
}

\begin{abstract}
As a newcomer to Canadian culture, I present an interpretive rendering of my encounters with settler and Indigenous relations. It is my humble attempt to respond to the Truth and Reconciliation Calls to Action ([TRC], 2015) for newcomers, by providing insight into what newcomers might experience in response to the complexities of Indigenous and settler dialogues. Newcomers are diverse groups, on the fringes of Indigenous-settler relations discourse, and outside of the protocols to enter such dialogues. Therefore, I ask, where and when can newcomers, temporary or long term, enter the dialogues in meaningful, respectful ways? I came to recognize that as a newcomer the more appropriate course of action would be to wait to be invited into the conversation; but that does not absolve me of the responsibility to inform myself about Indigenous-settler relations and confront my discomforts with how I am implicated in these relations. This led me to inquire, can newcomers be of value in the ways multiple ethnic groups live together, in a good way? Using a hermeneutic and mythopoetic lens I present a series of vignettes that attempt to grapple with these questions, to contribute to the discourse of responses to the Calls to Action (TRC, 2015).
\end{abstract}

\section{The Meeting of Multiple Words and Worlds}

...myths are actually truths about culture and conventional views of history that have both been deeply influenced by the stories of our country that we have been told in school. (Donald, 2009, p. 3)

For new Canadians, many of whom carry their own traumatic memories of colonial violence, racism, and oppression, finding common ground as Treaty people involves learning about the history of Aboriginal peoples and finding ways to build stronger relationships of solidarity with them.

(Truth and Reconciliation Commission, 2015, p. 312)

We call upon the federal government, in collaboration with the national Aboriginal organizations, to revise the information kit for newcomers to Canada.... (Truth and Reconciliation Commission, 2015, p. 315)

As a relative newcomer to Canadian culture I present an interpretive rendering of my encounters with the themes and concerns regarding settler and Indigenous relations which have unfolded around me. This paper is my humble attempt to consider how I may enter the dialogues between Indigenous and settler groups, through an examination of my shifting experiences and perspectives. I state upfront that I have much to learn from these 
difficult conversations when multiple worlds meet. I recognize that the weightiness of the work of the Truth and Reconciliation Committee ([TRC], 2015), and the complexities of Indigenous and settlers living side by side, are such that my outsider status may not be considered pertinent to the Indigenous-settler relationships still being worked out. However, I begin by asking, where and when can I enter the conversation in a meaningful, respectful way? How might migrant groups, temporary or long term, contribute to the revival and resurgence (Hanson, 2017) of Indigenous groups? Can outsiders be of value in the ways multiple ethnic groups learn to live together, in a good way?

I am a Saint Lucian who currently lives in Canada as a graduate student. I grew up in a bi-lingual fishing village, acutely aware of my island's multiple heritages. However, I was rather insulated from the trauma in that heritage, until I studied history in high school, even though evidence of that trauma was all around. I became a teacher within the disciplines of literary arts and language and communication studies, keenly sensitive to the ways that studying literature and languages tends to give readers the false sense that they are denizens of the world.

As a Caribbean national, identifying as an Anglophone and Francophone West Indian, history, sociology, and multiculturalism are inevitable parts of our intellectual discourse. Now, I am currently housed in a Canadian educational research program that is attuned to the discourse around the decolonisation of education, and I have found it overlaps with my leaning to a mythopoetic intellectual tradition (Leonard \& Willis, 2008). The mythopoetic may be thought of as a cosmology or lens whereby one critically interrogates narratives or myths which systematically disempower through erasure, to pull forth more culturally relevant, uplifting narratives which imagine more culturally sustaining narratives (see, Bishop, 2008). The poesis is the ability to imagine by deliberating including subterranean, ignored, marginalised narratives and harnessing their uncommon metaphors and symbols. For this paper, I used a mythopoetic lens to critically interrogate the narratives about Indigenous and settler groups and I re-appropriated Adichie (2009) to frame my discussion about the dangers of certain stories. Also, a mythopoetic framework allowed me to consider how these stories overlapped with my island's history of colonialism and cultural erasure.

I am also influenced by the hermeneutic concept of dialogue, language as an event of understanding, the encounter with the other, and the transformative power of understanding, for being different in the world, in a relational way (Gadamer, 2013). Hermeneutic philosophy privileges the question and answer dynamic of dialogue for arriving at understanding, on the basis that as humans we are always embedded in experiences, and always in the process of interpreting experience. Language, its questions and answers, unravel that which is difficult to understand, especially when it appears to be other than what we already understand. As Moules, McCaffrey, Field, and Laing (2015) have pointed out, hermeneutical questioning is informed by "a humility toward one's own not knowing, a genuine curiosity toward what the other might have to say" (p. 42) and this includes the goal of understanding, which goes beyond taking information for one's own ends. Through hermeneutics, the researcher lays out their prejudices as they are the foundations of interpretations (Gadamer, 2013). From this methodological frame, I crafted vignettes as a dialogical process of interrogating my prejudices and evolving understanding of this land where I now reside. 
In this discussion, I use written vignettes as data sources, specifically my graduate student course writings over the last few years where I felt the safety to broach a private dialogue with Indigenous peoples and settler groups. I also use as data my attempts to inform myself about Indigenous ways and settler encounters by attending public events and reading as widely as I could. I used hermeneutics to help me lay out my preunderstandings of narratives I have encountered, and I consider the narratives that were undone by my private efforts to enter the Indigenous-settler conversation. I use this paper as an imagined dialogue with Indigenous peoples and settler groups, in this public space. The mythopoetic lens serves to re-tell the vignettes with an imagined view of the possibilities for living with poly-ethnicity, poly-lingualism, poly-identities, as distinguishable from the term multiculturalism - which may easily slip into synonymous connotations for mono-culturalism and the homogeneity of assimilationist discourse.

\section{Seeking Kinship}

The Indigenous experience has many points of similarity with my Caribbean history. Eli Hirtle's film Storyhive (2016) evokes several affinities with my heritage and our national efforts to preserve our Saint Lucian language and cultural traditions (see, St. Hilaire, 2011). Throughout my viewing of the film, I kept thinking, this is so much like our Saint Lucian stories. I found myself agreeing with Hirtle (2016) and the people he interviewed. I tend to think that language is the conduit and repository of culture and identity. However, over the course of writing the vignettes included here, I kept thinking, "but this is not my story." I have been compelled to interrogate this back and forth of kinship as I live on the fringes of Indigenous-settler relations that I have not fully understood.

There are several things that I know now that I wish I had known sooner, so I pursue the interpretive process as: where might an outsider join the conversation already in progress? I frame these interpretations in terms of what it means to listen hermeneutically to be able to enter a conversation. Kimball and Garrison (1996) have stated "[t]o engage in conversation, then, is to undergo change. Through the creation of a mutual understanding, a person not only considers another's lifeworld, but also examines her own position in light of new questions" (p. 51). This paper is an imagining of how the dialogue between Indigenous and settler groups might look if expanded to include outsiders and their ongoing questions.

I wrote eight vignettes in a quest to understand Indigenous-settler discourse, recognizing that hermeneutics acknowledges that understanding is accompanied by the risk of misunderstanding. Hermeneutics, "as an attempt to stick with the original difficulty of life" (Caputo, 1987, p. 1) has influenced my decision to let the pieces remain disparate and messy, even while I have been influenced by a Gadamerian (2013) inclination to confront tradition, through dialogue. I do not see a simple conclusion or resolution, but I think it is an ongoing project of imagining the possible through the ability to ask questions. I think the onus is on all to facilitate the dialogue - settled groups and newcomersnotwithstanding the challenges in communicating cross-culturally. Nevertheless, the event of understanding is such that one is different in the world, even though it includes stumbling through the difficulty in understanding (Gadamer, 2013). 
While I was in the middle of this interpretive exercise, I asked my professors and peers: how can newcomers/ immigrants be included in those conversations between settler groups and Indigenous people? What is the risk of exclusion? How do we begin to transcend cross-cultural barriers in these encounters? Does one depend on an invitation to enter the conversation? The overriding response was that one should wait to be invited. It was not the response I expected to hear. I thought I was being a good houseguest by seeking kinship. However, after consulting resources such as Vowel (2016), I came to accept that I am on the margins and I can not barge in to take responsibility for speaking about Indigenous experiences no matter how strong an affinity I feel. My tension was that I felt implicated even while I was a bystander.

The following pieces are stories of my experiences as I became entwined in life as a newcomer to Canadian soil. They are not chronological, just as my understandings are not linear. They are not representative of any particular newcomer group, just as other newcomer groups may have other concerns I cannot imagine. The vignettes indicate my wrestling with the recommendation that I ought to wait for an invitation to join in the meeting of Indigenous and settler worlds/words even while I know I am implicated in my status on the margins.

September 21st, 2016

\section{A Lost Heritage}

Dear ,

I hope this correspondence finds you well. I have "landed" into my studies safely, and I am pleased to say this land is bountiful and welcoming. But you should know a few things.

When I visited two years ago my first outing was on Canada Day. I went to Prince's Island, a few days after I had literally landed. I came across a section hosting Indigenous performances, with traditional Indigenous wear, a tepee, music, drums, and people who looked like what I had imagined, based on the limited visibility in mainstream North American popular media. I was so excited to see them! Images from my history books came alive. You remember that one we used all through high school, The People Who Came (Norman, 1986). My other reaction was, "they are alive, the Europeans did not wipe them out as they did the Tainos and Kalinagos in the islands!" I was in awe of their presence. Every time I saw an Indigenous looking person I would have to try hard not to stare. Sometimes they looked very much like what I had imagined, physiologically speaking. And then there were times I realized I would easily mistake them for another ethnicity. For me they represented a world not annihilated and I thought that was remarkable. I expected them to have exotic accents so when I heard their Canadian accents, I had to face my ignorance and embarrassment when I thought I should have known better.

When I understood that they lived on reservations much like what I had heard about the United States, I began to cringe inside because my understanding of the reservation was that it symbolized disempowerment. Then as I began to move around a bit more and noticed some of them in the dingy parts of downtown, looking disenfranchised, something in me began to stir. What happened to my image of the Indigenous peoples? Why did they look so undignified? This was not what I saw at the staged ceremony, this was not what I expected. My history books came dishearteningly alive with a truer sense of The People 
Who Came, the settler groups who were wearing sharp suits and expensive shoes, walking briskly in and out of high-rise buildings downtown. The Indigenous were shuffling along the streets in clothes which had seen better days, speaking loudly in slurred speech. That was not what I had imagined.

When I returned to the city a year later, as a student, I had already shed my romanticized view of the Indigenous experience here. I recognized that to speak about Indigenous people, to the wrong person, could result in misinformation. I once overheard a newcomer disparagingly say, "they're always drunk." I wanted to respond, "you have no right to say that," but the words stuck in a place where I could not retrieve them. I sensed there were taboos about how to discuss Indigenous people, but I didn't know why. I found myself attending talks and lectures to make sense of my confusion. The more I discovered, the more disturbed I became. The feelings I had when I first encountered facts about the Trans-Atlantic middle passage, at about age fifteen, resurfaced. I recognized that some of the taboos were self-imposed. I had not wanted to know the depth of the challenges experienced by the Indigenous peoples because it would destroy my image of Canada. It would make me angry, and then I would feel pity, which is not imbuing a people with the dignity that is their human right to have. Then I would feel shame. I did feel all of that, but I had no place to process it. I am an outsider and outside of the history here. What right do I have to want to be a part of the conversation? And why would I want to experience their hurts when previously I thought their heritage was one of triumph over colonialism?

I attended lectures, I listened to my classmates, I listened to my professors. I listened to newcomers like myself, repeating some of what they had heard, without context, but I could not set these stories right because I had not begun to understand them myself. When one of my professors directed us to study the online curriculum about Indigenous history, in the public domain, I bristled. I did not want to know any of this. I took a distinct post-colonial outlook to the research task interpreting the online curriculum in terms of how it appeared to maintain imperial power structures. I examined the site: http://www.wherearethechildren.ca/en/. I began first by attempting to look at the site as if through the eyes of someone uninformed. I did not want to re-live my disappointments. What might a newcomer see first, I asked.

The site name is sufficiently provocative. The question "where are the children" evokes something lost. However, I found the site's front page, the font, and the layout, glamorous and sleek. It invites an audience to peruse further. The ease of clicking to move on to a next section if you want more information means that one can approach the site as if peeling off layers gradually. The front image of the boys looks like a modern photograph, but it is rendered in a sepia tone. The boys are seated in the grass, with a building in the background, as if the image is a candid shot because they are not looking into the camera. The boy in the foreground of the image has his forehead furrowed. There is something stark in the image. The children are not childlike. The building in the background looks like it could be a school.

I found that the site's opening pages offered raw facts such as "between 18311969 ," and one reads that the schools were established through arrangements between the Government of Canada and the churches, and the goal was assimilation of Indigenous peoples into colonial Canadian society. At that point, I had to suspend my pretense at looking with uninformed eyes. The site read as if the front pages are minimizing the 
discomfort of the reality, but I am still haunted by the images of the transformation of an Indigenous boy called Thomas Moore. And the renaming. Our names are our identities and the whole world of a nation within us.

Loss of heritage, loss of names. Isn't that our story too?

This is but one instance among a series of instances where my first impressions were overturned. This disruption of my expectations I bore privately. You may eventually find yourself landing somewhere with an image of a lost heritage, and no one to talk to. But understanding differently begins in the disruption of our expectations. I don't know what you understand of the Indigenous heritage in our islands and the heritage where I am now. What is difficult for me to communicate is that the heritage of stories which distort the reality of what existed is as painful as the heritage of reading about the middle passage for the first time. I'm trying to simplify it, but it's not as simple as that. If you remember the history books we studied in secondary school, The People Who Came (Norman, 1986), I am one of those people now, and strangely I am not. As Caribbean people we have always been in heritage limbo, but this one is a different kind of limbo. It is more than I can say, here and now.

If you do decide to leave your shores and visit, I hope you have an easier time of it. And I hope you have the courage to ask the questions I am reluctant to ask. I have not quite sorted my feelings on the subjects.

I am ever, yours truly,

\section{Interlude: You're Not the Indian I Had in Mind}

In Thomas King's (2002) The Truth About Stories, I appreciated the way King ushered his lecture in that he hints at the idea that we're all outcomes of multiple stories that have come before us. It helped me to approach the narratives of the Indigenous Peoples of North America with more reverence than I had before I came to Canada.

In mind.

Lest readers misunderstand, the Indian I had in mind was celebrated. Prior to my arrival here, I was excited to see and meet what I thought was an image of a relic of "my" historical past. The narrative of the islands was that native tribes were wiped out by European conquest. You've heard it before, the story of conquest, and disease, and strenuous labour. In the narrative of the islands, of course, there is the character of the benevolent Las Casas, who tried to save the Indians by recommending African labour. "We" got here, but they were wiped out anyway.

Nevertheless, the Indian I thought of was regal, unconquered, and most importantly, alive. Then I came to see that there was a colonized slant to Indian experience, and it was almost tempting to see so many overlaps with West Indian history-our storytelling, and our myths, our non-Western ontologies meeting Western ontologies, our splits and pluralities and the resultant social dis-eases. However, with every point of similarity, I came to see some differences. These were not the Indians I had in mind.

When I began to dig into my "West Indian history" to explore my affinity with the Indian experience, I found Castanha's research (2011) on the myth of Indigenous Caribbean extinction in Borikén (Puerto Rico). Castanha's research showed that in the colonial thrust to effect erasure, these people were silenced and even removed from the dominating narratives about history. With the power of pens, and dangerous storytelling, 
we hear of a genocide. We internalise that narrative, which is strategically and systematically passed on through formal schooling, only to find out, it might not be entirely true. It is like so many other stories created to silence and subdue.

The pen is mightier than the sword, is the power of language and the written word to destroy, even more swiftly and effectively than physical combat.

What stories have I taught, what languages have I erased in my teaching practice by repeating the monomyth of Indigenous extinction in the Caribbean? Is Iyanola the Indigenous name for Saint Lucia? What stories have been omitted in our literary arts curricula? What has been lost by being conquered?

We're outcomes of multiple stories which have come before us. How dangerous is that?

\section{Precarious Places and Spaces in Storytelling}

The stories I brought with me as a newcomer made me feel a kinship with Indigenous peoples. I have always felt fortunate to have been born and raised in the beauty of the Caribbean archipelago, and I once imagined, in an alternate reality, what if we never came across through the middle passage? Which Indigenous peoples would my ancestors be? How would we be living in those villages and mountains, off the land and the sea, in the abundance of a tropical environment that renews itself when uncorrupted by human exploitation?

Breathe.Maybe I should re-title this piece "the dangers of stories," because it is not just the mono which can subvert and misrepresent, but even poly-narratives. I had heard other stories about Indigenous peoples when I arrived. There were unflattering stories that I am ashamed to repeat, just because I listened, just because I was trying to understand why I had it all wrong. When I saw for myself, the absences of Indigenous people in the economic strongholds of the city center, when I researched for myself, and came to know about residential schooling, when I began to examine multiple narratives, I knew I could not claim what now seems like a partial affinity. The inclination to hold on to the stories of Indigenous peoples might have felt more real to me than the monoculture of North America; for the similarities to my worldviews and similar experiences of ethnic minorities confronting mighty socio-economic powers trying to erase languages; for the similarities in non-Western spirituality.

See what I have just done there-claimed a mono-culture when there is as much diversity from province to province in Canada, just as much as there is diversity from Eastern USA to the mid- west, to the North and South, to the West Coast; just as much as there is diversity within the Anglophone, Francophone, Hispanic Caribbean; just as much as there is diversity within Indigenous groups and to bundle them under one title is as dangerous as erasure.

I needed to read King (2012) to dismantle the monomyths I had created about Indigenous people. Inspired by his measured tone, I learnt how to read with a more measured response, and less acrimony than I would be wont to express. When I read The Break, by Metis author Katherena Vermette, as part of an assigned reading in a Curriculum Studies course, I found myself eager to read more Indigenous literature. I had moved from thinking they had triumphed over European colonization, to thinking they had been oppressed in their own homelands, to being unable to shake off how they resembled the 
diversity of my West Indian heritage. With a more careful, measured disposition I noted that encounters between the conquering and the could-be conquered are not single stories of ruptures, triumph, oppression, or surviving adversity. My first literary encounter with the Métis experience in The Break reminded me of how multiple heritages and ruptures from homelands converged to create a distinct Saint Lucian identity, Francophone, Anglophone, in some ways like the other islands in the archipelago, but so distinct we know ourselves to be ourselves. Like us, the Métis I saw in The Break have had to deal with multiple ruptures, being in between traditional and urban worlds, working out how to be true to themselves.

I was disappointed that I had not yet encountered this literature, which seemed to connect so well with the West Indian experience. The Break introduced me to contemporary Indigenous literature, and I felt altered by the way it broke up some of the monomyths about Indigenous peoples. Even though my monomyths were from a place of admiration and desire to feel the triumph of a people who resisted being colonized or obliterated, they were problematic for a range of reasons. It is not just that I was lacking truth or fact; but because I felt that I did not have dignified narratives from Indigenous peoples themselves. I had heard too many second-hand stories. I need to clarify my use of the word "dignified." There are places within, where no matter how much you mean well, you know you are inflicting an injustice. Indigenous people are not worthy of dignity because they survived while other tribes in other parts of the world died out, or because they have suffered racism and systemic oppression, like my ancestors, or because they have beautiful stories or wisdom traditions worth attending to. People do not need a reason for affording them the dignity of who they are. I do not need reasons (and there are enough as it is) to actively undo the dangerous monomyths about Indigenous people in my Caribbean heritage. It is a responsibility. But what of here, where I find myself now?

The affinity I feel with the Indigenous experience is not a falsehood, but I have to be careful with it. It takes me to a familiar place of distaste, distrust, disappointment with history. King (2012), says it more elegantly, more measured than I am inclined to say it, history isn't neutral.

Wary. Some stories stoke the narrative of the oppressed, and a resounding war against "Babylon." They can evoke my West Indian folklore which implores us to guard against spirit-thievery and zombification (Brodber, 1988).

Weary. Have selected wisdoms in the Western world come to recognize the demise of everything as we know it, within the ecological crisis, and platforms for alternatives to Western modes of thinking, are pursuits of survival? Are Indigenous ways of knowing/being/doing, the final unconquered terrain? Where have these untruths come from and what is this post-colonial cynicism bubbling up toil and trouble, without the appropriate spaces for dialogue, and militant deconstructionist, post- everything, ists and isms overtake any optimism for the possibilities of the imagination and imaging of living well together?

Breathe. The danger of a single story is that even when we seek out the other stories, they can easily become monomyths that trap a people, forever in limbo. As a 
progeny of splits, cultural splits between Europe and Africa, Old and New worlds, English and French languages, Euro-spiritual and Afro-spiritual, maybe I will always be split, always trying to understand the other. A part of me is always seeking out the underdog where real lives are lived, wary of the misleading fictions which become mainstream. Who decides the stories should we share?

The danger of the pen that shuts down dialogue is that only one set of stories gets to be told. I appreciated that Katherena Vermette's The Break also broke up those binaries and allowed me to see Indigenous lives with the richness that literary art can convey. The characters, especially Stella, Cheryl, and Tommy, in between worlds and identities, reminded me of the West Indian tensions of feeling one must align with either European, or African, or Asian heritages at the risk of alienating parts of one's identity, even though identity can't be disaggregated that way. I couldn't help but feel that this was a recurring struggle for several of the characters: choosing between Métis ways and city ways that minimized, thwarted, or vulgarized the connections to their Indigenous heritage. For me, The Break evoked the bittersweet satisfaction of a first-time reading of classical West Indian literature such as The Lonely Londoners by Samuel Selvon, and really seeing the poignant uncurrent of the lives I previously thought of as simple. Vermette's choice to include the characters' stories (teenagers, adults, seniors, the living, and the dead) as multiple perspectives throughout the novel was akin to the free indirect narration of multiple viewpoints in the oral narrative style of the The Lonely Londoners and this allowed me into emotional upheaval of the ruptures these characters experience. Told from their inner voices and not retold by outsiders, the characters in The Break, like those of The Lonely Londoners, find their relationship with land and heritage somewhat severed by the cruel, depersonalising, urban landscape, and the people who populate it, but the ability to find warmth and kinship with each other in their communities is an imagining that goes beyond a one-dimensional reading. Could that be part of what Hanson (2017) meant by reading for resurgence? Reading Indigenous literature allowed me to feel at home in a space where I know that I am still a stranger. That unexpected kinship is where I came to notice why I couldn't shake off the desire to be part of the Reconciliation conversation, regardless of whether I "settle" or move away.

\section{Interlude: What Kind of Indian Are You?}

You're West Indian, you say?

That's what I say.

There is yet another myth about the Indian, the one King (2002) and Vermette's (2016) The Break helped me confront-the myth of the gentle Indian. I have always asked, how come they're not like us, "West Indians," angry, revolting, and violent in response to the systemic effects of history, multiple colonial experiences, multiple mother countries, and multiple abandonments; multiple negations of identities and multiple cultural erasures?

The Break is a story that needs to be told, not only in Canada, but literary arts curricula in other parts of the world. The Break demythologizes the stories I had carried around with me as if they were irrefutable truths. Yes, The Break arouses old sentiments 
because I see familiar characters. Some are angry and revolting in different ways. There is violence. Some are hurting themselves and each other. How easy it is for the senior white police officer to ignore the violence in the Indigenous community because he is so disconnected, and perhaps, he sees it as violence against themselves. King $(2002,2012)$ and Vermette (2016) are by no means gentle, but in telling their stories with utmost dignity, I am schooled. I am reminded: I am not disconnected as long as I share a space and world with Indigenous and settler groups, whether it is temporary or long-term, and whether I'm of a minority ethnic or linguistic group.

I need to be careful about this strange kinship I feel when I hear or read stories about Indigenous peoples. I want to be careful about thinking I "get it", because some stories are partial. I feel like I'm pulled in and out of precarious territory when I confront these themes and sometimes, I would like to stay where it is safe. It's convenient to want to remain where it is safe, outside of the dialogue. I am an outsider and if I'm not invited, I may not come knocking at your door.

*Tim Tim

\section{Holding a Meditation}

\section{Bwa sèch \\ Ki sa ki assou la tè \\ Tout choz}

Memory: I am 10, minding my own business in my room. The sun has set, and the glaring slate of sea and sky has subdued into the gentle lilacs which will welcome the night. I can hear the tuning of instruments and not too long after, the music, which comes in bursts and spurts of a rehearsal, blesses my blood with long stretches of rhythm. The reggae beats strummed from higher up on the hill, reverberate all the way to my room, evoking something primal, not for dance, but something you could get lost in. The reggae band is called Itacion. Sometimes the singing is carried on the wind, downhill and I get wisps of the voices, just enough to feel the emotions behind the tunes even though I can't make out the words. Later as an adult, I come to understand it is a song which has become a classic in the community, "Polis mouté Morne Gimie."

This song is a story about Saint Lucia in the seventies when police raided Rastafarians living in the hills, off the land (Nobbie16, 2016). Their marijuana plantations were burnt down, a gesture which evoked another era of Saint Lucian history, plantation owners in pursuit of brigands in the mountains (Devaux, 1997), while today, young men are still jailed for the possession of marijuana. Here, in Canada, marijuana is as legal to purchase as wine. But as the well-behaved colonized peoples in Saint Lucia, we learnt how to prosecute and imprison our youth. What will roll into the future as an injustice righted? You see, one of the narratives persisting in the West Indian Afro-centric undercurrent is that we must tell the stories, lest we lose our spirits again. Which story gets told and celebrated, a people persecuted, or a people a nuisance? What kind of West Indian does one become in exile, flung wide in a diaspora that is so sparse, that when you hear the Indigenous story, you think it could be yours? But I'm an inconvenient (King, 2012) west Indian.

-an inconvenient rastaman, 
an inconvenient brigand,

an inconvenient indian,

an inconvenient woman,

an inconvenient land,

Multiple stories, similar narrative arc. Tread carefully.

If I had pursued my interest in historical stories, I would have continued to be angry with the present and the future, holding on to the militant streak I've seen in some of my peers and my students, burn strong, then burn out. It is so easy to be swept by feelings of helplessness, hopelessness, despairing of what Euro-worlds have taken and given.

i di kwik kwak*

*Traditional Saint Lucian call and response beginning and ending to oral storytelling. 


\section{A Mythopoesis of Memory}

child of Iyanola,

maybe my memories will slacken

and tensions of my inner turmoils will release the roiling wrought by the route here now, uninvited

a story will say

what kind of indian

do you think you are? what kind of west do you

think you'll be?

i belong here no more

than there and the there of

there

and the

other there

and many

theres

either i'm west

indian of the islands

or no one at all

either i'm west indian flanked by a sea and an

ocean or an entire nation

either i'm a

denizen or

stranger to all 


\section{A Heritage Re-viewed}

Coyote,

Legba,

Anansi,

Hermes,

Which trickster has worked on me here?

I don't have the trickster gift to use King's (2012) tongue-in-cheek tone to respond to history, and I am not always able to mollify my teenage self coming to understand the Trans-Atlantic middle passage and all the violent passages that brought me to the New World. My childhood self, disillusioned by the distortions of history, once thought: What would this New World be without the violent passage of that over-reaching Italian? Could I have been Kalinago, or Tainos?

I am not.

But the trickster has found itself in multiple iterations across worlds. Ain't I a woman? And able to feel a kinship with experience in worlds and words far from mine? I have something to learn from King (2012) about being less volatile, less bitter, less incensed. Sensitive and sensible? The danger, always just around the corner is the single, partial, even false story, which gets to be passed down as a truth. I turn to poetry when I need to breathe, especially Hippolyte's call to let go of it all, "Columbus and his frightened crew of felons" as well as "The Carib warriors of Sautuers Cliff who leaped to meet themselves" (Hippolyte, 2005, p. 36).

I keep going back to my touchstone, the literary arts, the words, the oral traditions, the songs, the stories, the poems, the stories.

The stories

The stories

The stories

Hanson's research (2017) made me realise that I have missed out on a wealth of storytelling that I had never heard about until I got here. Why didn't my undergraduate English program have the space to include literature about characters from Indigenous storytelling, such as Van Camp's (2019) terrifying stories of the "wheetago"? Yet I had to write numerous essays about the profound insight offered by Shakespeare. The Indigenous storytelling of the wheetago resembles the Caribbean soucouyant (see, Delisle, 2011), a mythical succubus figure that sucks the life out of the vulnerable and unprotected, or those who are not alert. I can't help but feel that when we speak of decolonisation of education, we are talking about ways to disarm the wheetago or soucouyant, those parts of our lives we have relinquished power to, depleting our energies and resources.

The stories

\section{Understanding Differently}

I used an interpretive outlook that was guided by hermeneutics and laid out my prejudices in order to better understand Truth and Reconciliation. I noted how my understanding of my identity as a literature teacher shifted through my private attempts to enter Indigenous-settler dialogues. Through the use of hermeneutic-influenced questioning in the selected vignettes and through "the withoutenness of how we appear in the other's narrative, there is some clue as to how we might come to understand ourselves differently 
and, perhaps, more completely" (Davey, 2006, p. 222). By not belonging to the dialogues, and yet seeing myself in the stories which I encountered as a newcomer, I found it unethical to remain as a bystander. This struggle manifested in the following anecdote.

Over points of similarity in our literacy teaching backgrounds, a classmate once shared their challenge in getting their students to participate more in classes, when the students came from an Indigenous background where listening was privileged over speaking prematurely. I suggested, "well who says they ought to be brought over to this principle that you value." Their response was, "but we want them to perform well and succeed, because they need to be able to function in this world, so they need these skills to excel here. Not trying to diminish their Indigenous ways, but how to get them to keep their ways and learn what they need for this environment." Mentally, my response was aggressive and acrimonious. I was hearing, "you can't play your drums, you can't speak your African languages, you can't practice your African religions because you are in the New World now and you need to learn to function and excel here, as your colonial motherlands have stipulated." That was my volatility evoking my socio-historical consciousness even though this history that I re-membered is several generations removed from me, in the past. I had not yet read King (2002) and learnt how to have a measured reaction.

Instead I offered, "maybe you need to modify your approach and go over to their way of seeing the world or their concept of learning and modify the instructions to suit them." They responded "hmm, well, yes, maybe that's the better angle" and the conversation ended. The classmate had said what I might have said before coming to graduate school, as a language and communications lecturer. They might not have seen the acrimony in my face. They might not have seen that I was trying to understand the other. I am not in any better a position now, because while I hold some colonialist, imperialist manifestations in education with some distaste, I do not have many alternatives for the organized way of learning from which I benefited tremendously. Now I name it as cultural erasure, under the mantle of meaning well.

I can't reconcile the nuances of assimilation in educational discourse. I go back to what I have long believed: language is the gourd of culture and identity. What violent erasure are we affecting by insisting that literacy educational practices privilege a monotradition when we speak now of decolonisation of education (see, Battiste, 2013; Patel, 2015)? Do we dare consider the decolonisation of language instruction? Assimilation can be perceived in terms of how the minority group absorbs the values of the dominant culture, sometimes by the force of the dominant group, and as Clark (2007) pointed out, it has very problematic associations. What concerns me moving forward is that if newcomers remain on the fringes of the dialogues, they are likely to pursue assimilation, inclusive of its discrimination and oppression. I don't think I ought to repeat the whisperings I have heard to hammer that point home. Therefore, Indigenous groups may find their truth telling supported by allies in newcomers.

As a West Indian, assimilation holds a negative connotation of cultural erasure or spirit thievery, while, I imagine, for some it might be viewed as community building. My understanding is that even now, when there is an effort to understand Indigenous ways (Innes, 2009), it can be suspiciously viewed as exploitation and not assimilation. Schiebinger (2017) best explains my West Indian worldview — we are careful, strategically holding secrets, because we are wary of "spirit thievery" (Brodber, 1988). The Indigenous 
experience is different from my heritage of being wrenched from motherlands, because in some ways, they are still close to their ancestral lands. But with children wrenched from their families in the residential school experience, they too, have had to grapple with spirit thievery, and that is where I could begin our conversations.

How do I speak with settler groups? That holds another level of discomfort, but I subscribe to Coates's $(2014,2019)$ argument for reparations for African Americans, as to why reconciliation goes beyond words and requires action. It is challenging for me to be immersed in that kind of dialogue with my colleagues because I think it is difficult for some educators to admit how they endorse social injustices. Clark (2007) declared that "Canadian history textbooks have not yet come to grips with what means within a postcolonial settler society [and that] the narrative in Canadian history textbooks is overwhelmingly one of progress" (p. 111). Up to this point, I conclude that history in Canada is told with a euphemistic tone and my commitment to attempt to enter the dialogue with respect for protocols and cultures is fraught with tension. I have understood that Canada is still working out how to tell the stories, how to make amends, how to move forward, and by extension, some educators have not determined how to engage in the discussion. I recognize that there are tremendous efforts on all fronts and that the difficulties are parts of the larger narrative which includes triumphs and travails. Nevertheless, settler groups may need to push past these difficulties for genuine reconciliation.

\section{Post-Script: To Disarm the Wheetago or Soucouyant}

While composing these responses to my overarching question, do I wait for an invitation to enter the dialogue? I resolved, against my desire to tactfully slide into the dialogues, I should wait. That was not the response I was looking for, but by looking at the uncomfortable assumptions when I began writing these vignettes, I see it as the most ethical way to proceed. Although "a fascination with the historical and linguistic horizons that form us, an enduring respect for the voices that truly speak to us, and a love for the other who reveals one's own mystery to oneself," (Davey, 2006, p. 222) suggest an intimacy and kinship that I cleave to, especially as a newcomer, I should wait for the invitation. And while waiting, what can I do? What may other newcomers do?

I am not a settler by Vowel's (2016) terms, but I see the danger of ignoring that I am living within the terms dictated by settler groups and at the risk of internalising the dominating, often erroneous narrative. Therefore, I bear the weight of settler discourse. When can a newcomer prepare to enter the dialogue and ethically endure that unexpected weight of settler discourse? From the very moment they decide to set foot here. There are perspectives which assert that Black people should show up for Indigenous folks and viceversa (Thomas, 2019). I am newly aware of myself as a minority, but my work should not be limited to my experience as a minority. Where can I enter the dialogues? Perhaps at the points where I have taken responsibility to do the work of being a good neighbour and that includes trying to understand the experiences of all ethnic groups in this space I now reside. I should not wait to be an expert to accept a possible invitation to enter the dialogue. Entering the dialogue does not mean barging in with a perspective fully developed. It may include waiting in silence, listening, asking questions, asserting misconceptions, making mistakes, and creating spaces for reconciliation. Even though I am not responsible for a history already in play, I am responsible for the present and the future. Indigenous, settlers, 
and newcomers "should not ignore the fact that the future remains a closed book so long as the consciousness of the people remains imperfect, elementary, and cloudy" (Fanon, 1963, p. 193).

Hampton and DeMartini (2017) began their re-counting of research on place-based learning for teacher-educators by pointing out that teachers are the central storytellers in their classrooms making "conscious and subconscious decisions about what to pass on to their students" (p. 247), and when they asked: "As future teachers, what stories will they then bring into their classrooms?" (p. 248), I wondered, what stories will other newcomers hear? Who will do the work of unearthing the stories and mis-stories which grow like GMO weeds? If I bear the weight of settler discourse, then I have to concede that my presence here is not neutral and I am embedded in structures where "research and researchers who have succeeded have been validated through settler colonial structures of schooling and consequently are answerable, minimally, to working to dismantle those structures" (Patel, 2015, p. 74). It would be unethical to hide behind a newcomer status for me. By extension, it would be unethical for newcomers to take a hands-off approach to Truth and Reconciliation, especially for the relations which have made it possible for us to be here.

\section{References}

Adichie, C. N. (2009, October 7). The danger of a single story Chimamanda Ngozi Adichie TED Talks [Video file]. Retrieved from https://www.youtube.com/watch?v=D9Ihs241zeg

Battiste, M. (2013). Decolonizing education: Nourishing the learning spirit. Vancouver, BC: Purich Publishing Limited.

Bishop, P. (2008). The shadow of hope: Reconciliation and imaginal pedagogies. In T. Leonard, \& P. Willis, (Eds.). (pp. 31-51). Pedagogies of the imagination: Mythopoetic curriculum in educational practice. Berlin, Germany: Springer Science \& Business Media.

Brodber, E. (1988). Myal. New Beacon. Caputo, J. D. (1986). Radical hermeneutics: Repetition, deconstruction, and the hermeneutic project. Bloomington, IN: Indiana University Press.

Castanha, T. (2011). The myth of indigenous Caribbean extinction: Continuity and reclamation in Borikén (Puerto Rico). London, UK: Palgrave Macmillan.

Clark, P. (2007). Representations of Aboriginal Peoples in English Canadian history textbooks: Toward reconciliation. In E. A. Cole (Ed.), Teaching the violent past: History education and reconciliation (pp. 81-120). Plymouth, UK: Rowman \& Littlefield and Carnegie Council for Ethics in International Affairs.

Coates, T-N. (2019, June 10). Ta-Nehisi Coates revisits the case for reparations. The New Yorker. Retrieved from https://www.newyorker.com/news/the-new-yorker-interview/ta-nehisi-coatesrevisits-the-case-for-reparations

Coates, T-N. (2014, June). The case for reparations. The Atlantic. Retrieved from https://www.theatlantic.com/magazine/archive/2014/06/the-case-forreparations/361631/

Davey, N. (2006). Unquiet understanding: Gadamer's philosophical hermeneutics. 
New York, NY: State University of New York Press.

Delisle, J. B. (2011). “A bruise still tender”: David Chariandy's Soucouyant and cultural Memory. Ariel: A Review of International English Literature, 41(2), 1-21.

Devaux, R. J. (1997). They called us brigands: The saga of St. Lucia's freedom fighters. Toronto, ON: Optimum Printers.

Donald, D. (2012). Forts, curriculum, and ethical relationality. In N. Ng-A-Fook, \& J. Rottmann (Eds.), Reconsidering Canadian curriculum studies (pp. 39-46). London, UK: Palgrave Macmillan.

Fanon, F. (1963). The wretched of the earth. Pref. by Jean-Paul Sartre. Translated [from the French] by Constance Farrington. New York, NY: Grove Press.

Gadamer, H-G. (2013). Truth and method ( $2^{\text {nd }}$ rev. ed.). (J. Weinsheimer \& D.G. Marshall, Trans.). London, UK: Bloomsbury Academic.

Gadamer, H.-G. (2006). Language and understanding (1970). Theory, Culture \& Society, 23(1), 13-27. https://doi.org/10.1177/0263276406063226

Hampton, R., \& DeMartini, A. (2017). We cannot call back colonial stories: Storytelling and critical land literacy. Canadian Journal of Education, 40(3), 245-271.

Hanson, A. (2017). Reading for resurgence: Indigenous literatures, communities, and learning (Unpublished doctoral dissertation). University of Calgary, Calgary, AB. Retrieved from http://hdl.handle.net/11023/3496

Healing the legacy of the residential schools. (n.d.). Retrieved March 10, 2016, from http://wherearethechildren.ca/en

Hippolyte, K. (2005). Night vision. Evanston, IL: TriQuarterly Books/Northwestern University Press.

Innes, R. A. (2009). "Wait a Second. Who Are You Anyways?": The insider/outsider debate and American Indian Studies. American Indian Quarterly, 33(4), 440-461.

Kimball, S., \& Garrison, J. (1996). Hermeneutic listening: An approach to understanding in multicultural conversations. Studies in Philosophy and Education, 15, 51-59.

Kimmerer, R. W. (2013). Braiding sweetgrass: Indigenous wisdom, scientific knowledge and the teachings of plants. Minneapolis, MN: Milkweed Editions.

King, T. (2012). The inconvenient Indian: A curious account of Native People in North America. Toronto, ON: Anchor Canada.

King, T. (2002). The truth about stories. Toronto, ON: House of Anansi Press.

Leonard, T., \& Willis, P. (Eds.). (2008). Pedagogies of the imagination: Mythopoetic curriculum in educational practice. Berlin, Germany: Springer Science \& Business Media.

Moules, N. J., McCaffrey, G., Field, J. C., \& Laing, C.M. (2015). Conducting hermeneutic research: From philosophy to practice. Bern, Switzerland: Peter Lang.

Nobbie16. (2016, September 8). Police Monteé Morne Gimie - Itación [Video file]. Retrieved from https://www.youtube.com/watch?v=TuSzeKsJx-w\&t=78s

Norman, A. (1986). The people who came: Book 1. Kingston, Jemaica: Longman Caribbean.

Patel, L. (2015). Decolonizing educational research (Series in Critical Narrative). New York, NY: Routledge.

Schiebinger, L. (2017, August 14). The hidden stories of medical experimentation on 
Caribbean slave plantation. The Conversation. Retrieved from

https://theconversation.com/the-hidden-stories-of-medical-experimentation-oncaribbean- slave-plantations- 81600

Selvon, S. (1985). The lonely Londoners. London, UK: Longman.

St-Hilaire, A. (2011). Kwéyòl in postcolonial Saint Lucia: Globalization, language planning, and national development. Amsterdam, Netherlands: John Benjamins Pub. Co.

Storyhive. (2016, November 22). Voices on the rise [Video file]. Retrieved from https://www.youtube.com/watch?v=jbX5qmxC78o.

Tomkins, G. S. (1986). A common countenance: Stability and change in the Canadian curriculum. Toronto, ON: Prentice-Hall Canada.

Thomas, A. (2019, February 15). Who is a settler, according to Indigenous and Black scholars. VICE. Retrieved from https://www.vice.com/en_ca/article/gyajj4/whois-a-settler-according-to indigenous-and-black-scholars

Truth and Reconciliation Commission (TRC). (2015). Honouring the truth, reconciling for the future. Summary of the final report of the Truth and Reconciliation Commission of Canada. Ottawa, ON: Truth and Reconciliation Commission of Canada. Retrieved from http://www.trc.ca/assets/pdf/Honouring the_Truth_Reconciling_for_the_Future July_23_2015.pdf

Van Camp, R. (2019). Moccasin square gardens: Short stories. Vancouver, BC: Douglas \& McIntyre.

Vermette, K. (2016). The Break. Toronto, ON: House of Anansi Press.

Vowel, C. (2016). Indigenous writes: A guide to First Nations, Métis \& Inuit issues in Canada. Winnipeg, MB: Highwater Press.

Author's Biography

Galicia Blackman is a PhD candidate in Educational Research, specializing in Curriculum and Learning at the Werklund School of Education, University of Calgary. A graduate of The University of the West Indies, she taught Literature and Communication Studies at the post-secondary level in the Caribbean, worked in curriculum reform, and fostered extracurricular learning activities in the arts. Her concern with the disparity between formal curriculum and students' lived experiences led her to research interests in students' learning experiences, dialogic pedagogy, student voice, and aesthetics in formal learning contexts, using hermeneutics in educational research, and the lens of the pedagogy of discomfort. 